\title{
Factors associated with treatment interruption for hepatitis C
}

\author{
Luciana Oliveira de Rezende Meloº ${ }^{1}$ Denise Leite Maia Monteiro², Nádia Cristina Pinheiro Rodrigues ${ }^{3}$ \\ 1 PhD in Medical Sciences - Medical Sciences Graduate Program at UERJ; Master Associate Professor at Universidade do Grande Rio (UNIGRANRIO) / Assistant Professor at Universidade Estácio de Sá, Rio de \\ Janeiro, RJ, Brazil. \\ ${ }^{2}$ Associate Professor at FCM/UERJ; Full Professor at UNIFESO (Teresópolis), Teresópolis, RJ, Brazil \\ ${ }^{3}$ Associate Professor at the Department of Information Technologies and Health Education, Faculdade de Ciências Médicas (FCM) / Rio de Janeiro State University (UERJ); a member of the \\ Graduate Medical Sciences Program at FCM/UERJ; Researcher at the National School of Public Health/Oswaldo Cruz Foundation (FIOCRUZ), Rio de Janeiro, RJ, Brazil.
}

\begin{abstract}
SUMmARY
Study carried out by the Hospital Federal dos Servidores do Estado do Rio de Janeiro, Rio de Janeiro, RJ, Brazil.

Article received: $2 / 21 / 2013$ Accepted for publication: $7 / 1 / 2013$

Correspondence Rua Dois de Dezembro, 113/1001 Flamengo - Rio de janeiro, RJ, Brazil ZIP Code: $22220-040$ lu.rezende@terra.com.br

http://dx.doi.org/10.1590/1806-9282.60.01.008 Conflict of interest: none

Objective: To evaluate risk factors related to Hepatitis $\mathrm{C}$ treatment interruption. Methods: Retrospective cohort of patients seen at the Hepatology outpatient service at Hospital dos Servidores do Estado do Rio de Janeiro, from 2001 to 2009. The factors investigated were: age, gender, genotype, degree of liver fibrosis, type of treatment, treatment time in weeks, diabetes mellitus, and systemic hypertension. Survival curves and bivariate and multivariate Cox regression models were used in the analyses.

Results: The risk of treatment interruption is six times greater in patients with more advanced degrees of liver fibrosis (F4) compared to those with less advanced degree (F2) in the period from 0 to 24 weeks of treatment. Genotype was found to be an important factor to explain therapy cessation after 24 weeks of treatment - the risk of stopping treatment was 2.5 times higher in patients with genotype 3 than in those with genotype 1.

Conclusion: Degree of liver fibrosis and genotype proved to be the main risk factors associated to treatment interruption.

Uniterms: Hepatitis C; interferons; ribavirin; treatment cessation; risk factors.

\section{INTROUCTION}

Infection with the hepatitis $\mathrm{C}$ virus (HCV) has a worldwide distribution, affecting $3 \%$ of the world population. ${ }^{1}$ It is estimated that close to 210 million people are infected throughout the world; in Brazil, prevalence is at $1.38 \%{ }^{2.3}$ Approximately $85 \%$ of the cases of infection are expected to progress to chronic disease, and 10 to $20 \%$ will develop cirrhosis over a period of 20 to 30 years, which can lead to liver failure, hepatocellular carcinoma, and death. ${ }^{4}$

The treatment is aimed at preventing the progression of infection by inhibiting virus replication. ${ }^{5}$ Therefore, therapy has as its objective sustained virologic response (SVR), which means undetectable HCV-RNA six months after treatment, and delay in progression to liver cirrhosis and its complications, improving both the life expectancy and life quality of infected patients. ${ }^{6}$ To indicate the treatment, one should consider the risk of disease progression, the probability of therapeutic response, adverse effects of treatment, and the presence of comorbidities. ${ }^{2}$

In Brazil, until 2011, treatment was based on the combination of interferon alpha (INF) and ribavirin (RBV), or pegylated interferon (PEGINF) with RBV.? After three large studies were published ${ }^{8,9,10}$ showing the superiority of PEGINF combined with RBV compared to INF combined with RBV, with better SVR rates, the Clinical Protocol and Therapeutic Guidelines for Viral Hepatitis $C$ has been revised and currently recommend treatment with PEGINF combined with RBV during 48 weeks for genotype 1, and 24 weeks for genotypes 2 or $3 .^{2}$

Simmonds (2005) described six genotypes for HCV (numbered 1 to 6 ), in addition to several subtypes. ${ }^{11}$ Genotype 1 is the most prevalent worldwide, as well as in Brazil, with rates at $64.9 \%$ in our country. ${ }^{12}$ Also, genotype 1 is associated with lower SVR rates. ${ }^{2}$

The main predictors of response to treatment are low viral load previous to treatment and non-1 genotype..$^{8,9,10}$
\end{abstract}


Other predictive factors identified are: gender, age, insulin resistance, BMI and degree of liver fibrosis on hepatic biopsy.

According to the literature, patients with liver cirrhosis clinically established as well as patients with more advanced degree of fibrosis on histology, have lower rates of SVR compared to patients without liver cirrhosis and with lower degree of fibrosis. In addition, these patients are more likely to stop treatment because subjects with liver cirrhosis are more prone to the adverse effects of therapy on account of the condition itself. ${ }^{13}$

The objective of this study is to evaluate whether the type of treatment, genotyping or the degree of liver fibrosis interfere with the risk of interrupting treatment of hepatitis C.

\section{Methods}

\section{Study design}

Historical cohort in which a retrospective survey was conducted including patients seen at the Hepatology outpatient service of Hospital dos Servidores do Estado do Rio de Janeiro (HSE) during the period from 2001 to 2009, to assess the risk of treatment interruption. Data were collected through active search in the service's patient records.

\section{Study population}

Of the 193 patients with hepatitis C initially selected, three were excluded because they had been treated with interferon only, totaling 190 patients.

\section{Eligibility criteria}

Having hepatitis $C$, being 30 years old or older, having genotype 1 or 3 (regardless of subtype), presenting as degree of liver fibrosis F2, F3 or F4 (according to the Metavir criteria: F2 - portal fibrosis with some septa; F3 - many septa without cirrhosis; e F4 - cirrhosis), having received treatment with pegylated interferon for the first time (alpha 2a or alpha $2 \mathrm{~b}$ ) combined with ribavirin (PEGINF $+\mathrm{RBV}$ ) or interferon-alpha combined with ribavirin (INF + RBV).

The study period was prior to the clinical protocol for treatment of hepatitis $C$ reported in 2011, which states that patients with genotypes 2 and 3 are treated with PEGINF + RBV for 24 weeks and those with genotype 1 with PEGINF + RBV for 48 to 72 weeks. $^{2}$

\section{Statistical analysis}

The factors investigated were: age (30-39; 40-49; 50-59; $3_{60}$ ), gender, genotype $(1 ; 3)$, degree of liver fibrosis (F2; F3; F4), type of treatment (INF + RBV; PEGINF + RBV), time of treatment in weeks, diabetes mellitus and high blood pressure.

The variable studied was the interruption of the treatment of hepatitis $\mathrm{C}$ during the following periods:

1) 0-24 weeks of treatment (patients that continued being treated after the first 24 weeks were excluded by the end of the study);2) 25-48 weeks of treatment (patients who received treatment for less than 25 weeks were excluded from this stage of study). Patients who remained on treatment after the first 24 weeks were excluded by the end of the study.

Absolute and relative frequencies were calculated for categorical variables. Chances of remaining in treatment were calculated over the period (48 weeks). Statistical tests were performed to compare the proportion of patients who remained in treatment during the period according to the genotype, degree of liver fibrosis and type of treatment. Bivariate Cox regression models were used to assess the association between predictors and the likelihood of stopping treatment. Multivariate analyzes were also performed to assess the association between degree of liver fibrosis and treatment interruption, genotype and treatment interruption, and type of treatment and treatment interruption. The covariates included in the model were: degree of liver fibrosis, type of treatment, age, gender and genotype.

All analyzes were performed with the software programs Epi Info (version 3.5.3) and R-Project ${ }^{\mathrm{TM}}$ (2.15.2).

The study was approved by the Research Ethics Committee at Hospital dos Servidores do Estado do Rio de Janeiro - HSE (informed opinion no. 000.387).

\section{Results}

Table 1 describes the general characteristics of the study participants. Among the patients studied, $87.4 \%$ were between 30 and 59 years old at the time of the study, with only $12.6 \%$ aged 60 years or older. Regarding gender, $49 \%$ were male and $51 \%$ female. Type 3 genotype was present in $48.9 \%$ of participants, and the remainder $(51.1 \%)$ had type 1 genotype.

Among patients who underwent liver biopsy, 8.9\% were diagnosed as F4, $64.8 \%$ as F3, and $26.3 \%$ as F2. High blood pressure was present in $22.6 \%$ of patients and diabetes, in $7.9 \%$. Among the patients that were treated, $27.9 \%$ stopped treatment. For most of the patients who continued being treated, the drug therapy was prescribed for 48 weeks (51.1\%); only $21 \%$ were prescribed treatment for 24 weeks. Regarding medication use, $52.6 \%$ of participants received pegylated interferon + ribavirin, and the others received interferon + ribavirin. 
TABLE 1 Frequency distribution of the main factors related to hepatitis $C$ treatment interruption in patients in Rio de Janeiro's Hospital dos Servidores do Estado, 2001-2009 Characteristics \begin{tabular}{l|l}
$n=190$ & $\%$
\end{tabular}

Age range

30 - 39 years

40 - 49 years

50 - 59 years

60 years or +

\begin{tabular}{|l|l|}
\hline 42 & 22.1 \\
\hline 63 & 33.2 \\
\hline 61 & 32.1 \\
\hline 25 & 12.6 \\
\hline
\end{tabular}

\section{Gender}

\begin{tabular}{l|l|l}
\hline Male & 97 & 49 \\
\hline Female & 93 & 51 \\
\hline
\end{tabular}

\section{Genotype}

\begin{tabular}{l|l|l}
\hline 1 & 173 & 51.1 \\
\hline 3 & 23 & 48.9 \\
\hline \multicolumn{2}{l|l}{} \\
\hline Degree of liver fibrosis ${ }^{1}$ & 47 & 26.3 \\
\hline F2 & 116 & 64.8 \\
\hline F3 & 16 & 8.9 \\
\hline F4 & 43 & 22.6 \\
\hline Diabtemic hypertension mellitus & 15 & 7.9 \\
\hline Time of treatment & \multicolumn{2}{l}{} \\
\hline 24 weeks & 40 & 21 \\
\hline 48 weeks & 97 & 51.1 \\
\hline Treatment interruption & 53 & 27.9 \\
\hline
\end{tabular}

\section{Type of treatment}

\begin{tabular}{l|l|l}
\hline INF $^{+} \mathrm{RBV}^{1}$ & 90 & 47.4 \\
\hline PEGINF+RBV & \\
\hline Response at end of treatment & 100 & 52.6 \\
\hline Sustained viral response & 84 & 44.2 \\
\hline
\end{tabular}

$1 \mathrm{INF}+\mathrm{RBV}$ : interferon + ribavirin, $2 \mathrm{PEGINF}+\mathrm{RBV}$ : pegylated interferon + ribavirin
Table 2 shows the relationship between key risk factors and the probability of stopping the treatment of hepatitis $\mathrm{C}$ in the period from 0 to 24 weeks. Bivariate analyses using Cox model (left side of the table) indicated that the degree of liver fibrosis interferes with the risk of therapy cessation $(\mathrm{RR}[\mathrm{F} 4 / \mathrm{F} 2]=6.07$, $\mathrm{p}$ <0.006). Adjusting the model for age, gender, type of treatment and genotype, the relationship between the degree of liver fibrosis and the risk of treatment interruption persists, indicating that the risk of stopping treatment for patients with grade F4 fibrosis is approximately six times greater than for those with F2 fibrosis. There was no association between liver fibrosis and treatment interruption for patients with degree F3 of liver fibrosis compared with F2 degree. There was also no evidence that the type of treatment influenced the probability of treatment cessation ( $\mathrm{p}<0.37$ ).

Table 3 shows the relationship between key risk factors and the likelihood of discontinuing treatment for patients prescribed 48 weeks of drug therapy who did not stop treatment until week 24 . In the bivariate analysis using Cox model (left side of table), no statistically significant association between the investigated factors and the risk of treatment interruption was found, but the results of the relationship between genotype and treatment interruption were borderline $(\mathrm{p}<0.06)$. Adjusting the model for age range, gender and degree of liver fibrosis (F3/F2), the relationship between genotype and treatment interruption proved to be significant $(p<0.02)$, indicating that the risk of stopping treatment after the first 24 weeks is influenced by genotype (patients

TABLE 2 Risk of treatment interruption during the first 24 weeks of initiating therapy, according to the main risk factors 190 patients from Hospital dos Servidores do Estado, 2001-2009

\begin{tabular}{|c|c|c|c|c|c|}
\hline Risk Factors & Categories & Bivariate analysis $\mathrm{HR}^{5}$ (Cl 95\%) & P-value & Multivariate analysis HR (CF 95\%) & P-value \\
\hline \multirow[t]{3}{*}{ Age Range } & $40-49 / 30-39$ & $1.09(0.39-2.99)$ & 0.87 & $0.80(0.28-2.28)$ & 0.77 \\
\hline & $50-59 / 30-39$ & $1.37(0.51-3.64)$ & 0.53 & $1.15(0.42-3.17)$ & 0.68 \\
\hline & ${ }^{3} 60 / 30-39$ & $2.29(0.77-6.81)$ & 0.14 & $0.98(0.26-3.69)$ & 0.98 \\
\hline Gender & fem/male & $0.96(0.49-1.86)$ & 0.89 & $1.10(0.53-2.32)$ & 0.79 \\
\hline Genotype & $3 / 1$ & $1.27(0.49-3.26)$ & 0.63 & $1.07(0.61-1.89)$ & 0.8 \\
\hline Degree of Liver & F3/F2 & $1.54(0.57-4.14)$ & 0.4 & $1.52(0.57-4.11)$ & 0.4 \\
\hline Fibrosis $^{1}$ & $\mathrm{~F} 4 / \mathrm{F} 2$ & $5.10(1.62-16.07)$ & $0.006^{*}$ & $6.07(1.84-20.06)$ & $0.003^{*}$ \\
\hline $\mathrm{HBP}^{2}$ & no/yes & $0.55(0.21-1.41)$ & 0.21 & & \\
\hline Diabetes Mellitus & no/yes & $1.53(0.54-4.23)$ & 0.42 & & \\
\hline Type of Treatment ${ }^{3}$ & $\begin{array}{l}\text { INF+RBV/ } \\
\text { PEGINF+RBV }\end{array}$ & $0.84(0.43-1.63)$ & 0.6 & $0.70(0.32-1.53)$ & 0.37 \\
\hline
\end{tabular}

1According to the Metavir criteria: F2 - portal fibrosis with some septa; F3 - many septa without cirrhosis; F4 - cirrhosis. 2HBP: high blood pressure;

3INF+RBV: interferon + ribavirin, PEGINF+RBV: pegylated interferon + ribavirin

4Covariables included in the model: degree of hepatic fibrosis, genotype, type of treatment, age and gender 5 HR: risk rate 
with genotype 3 have 2.5 times higher risk of interrupting treatment after 24 weeks than those with genotype 1 ).

\section{Discussion}

There are, in the literature, studies on the risk factors that influence the response to treatment of hepatitis $\mathrm{C}$ and studies on adverse effects that affect treatment interruption. Nevertheless, studies correlating risk factors with therapy cessation are scarce.

Adverse effects of treatment promote low quality of life to patients, which could negatively influence the trust of these individuals and contribute to discontinuation of therapy. ${ }^{1.2,3}$ Interdisciplinary support to deal with the side effects, including support and motivation strategies, help to reduce the risk of early dropout. ${ }^{2.3}$

In this study, no association was found between age and treatment interruption. Kim et al. (2012) found that older patients are more prone to adverse effects than younger subjects, which could lead to cessation of the therapy. ${ }^{14}$

Likewise, no association was found between sex and treatment interruption, corroborating the literature data. However, Deutsch M et al. (1997) showed that certain adverse effects, more common among women, as the occurrence of hypothyroidism, may lead to cessation of therapy. ${ }^{15}$

Combination therapy with INF + RBV or PEGINF + $\mathrm{RBV}$ is associated with side effects that can lead to dose reduction or treatment interruption. ${ }^{16}$ Our findings indicated no association between the type of therapy and treatment interruption. The side effects of INF and PEGINF are similar because both are considered interfer- ons, i.e., immunomodulators belonging to the family of cytokines; the difference between them is that the PEGINF has a polyethylene glycol molecule in its composition, which makes it a longer-lasting drug that can be administrated weekly for the treatment of hepatitis $\mathrm{C}$, unlike INF, which is administrated three times per week. ${ }^{9.10}$ Thus, the risk of treatment interruption is higher during the 48-week schedule due to the increased likelihood of side effects, regardless of the type of treatment. ${ }^{8.9,10}$

Hematologic adverse effects caused by INF and PEGINF (thrombocytopenia and neutropenia) and RBV (anemia) are more common in cirrhotic patients, and this is a common reason for treatment interruption. ${ }^{17.18}$ This is probably due to the fact that the more severe the liver cirrhosis is (and hence the greater the degree of hepatic fibrosis detected on biopsy), the greater the chance of the patient having hematological abnormalities prior to treatment. ${ }^{910}$ In this study it became clear that the greater the degree of hepatic fibrosis, the greater the likelihood of treatment interruption in 24 weeks.

Regarding the relationship between the comorbidities investigated (hypertension and diabetes mellitus) and treatment interruption, the present study found no statistically significant association. In patients with high blood pressure, hypertensive peaks can occur as a side effect of treatment. ${ }^{19}$ Some studies also report that the prevalence of $\mathrm{HCV}$ infection in type 2 diabetic patients is higher than seen in the general population. ${ }^{20.21}$ In addition, there are reports in the literature that patients with insu-

TABLE 3. Risk of treatment interruption after 24 weeks of starting therapy, according to the main risk factors - 104 patients in Rio de Janeiro's Hospital dos Servidores do Estado, 2001-9

\begin{tabular}{|c|c|c|c|c|c|}
\hline Risk factors & Categories & $\begin{array}{l}\text { Bivariate } \\
\text { analysis } \\
\operatorname{HR}^{5}(\mathrm{Cl} 95 \%)\end{array}$ & P-value & $\begin{array}{l}\text { Multivariate analysis }{ }^{4} \\
\text { HR (Cl 95\%) }\end{array}$ & P-value \\
\hline \multirow[t]{3}{*}{ Age range } & $40-49 / 30-39$ & $0.75(0.19-3.02)$ & 0.69 & $0.59(0.14-2.49)$ & 0.47 \\
\hline & $50-59 / 30-39$ & $2.21(0.02-1.90)$ & 0.17 & $0.18(0.02-1.67)$ & 0.13 \\
\hline & $60^{3} / 30-39$ & $2.03(0.37-11.08)$ & 0.41 & $2.83(0.48-16.7)$ & 0.25 \\
\hline Gender & $\mathrm{fem} / \mathrm{male}$ & $1.35(0.41-4.41)$ & 0.62 & $1.62(0.44-5.96)$ & 0.47 \\
\hline Genotype & $3 / 1$ & & 0.066 & $2.71(1.19-6.20)$ & $0.02 *$ \\
\hline $\begin{array}{l}\text { Degree of liver } \\
\text { fibrosis }^{1}\end{array}$ & $\mathrm{~F} 3 / \mathrm{F} 2$ & $1.02(0.27-3.85)$ & 0.98 & $1.00(0.26-3.89)$ & 1.00 \\
\hline $\mathrm{HBP}^{2}$ & no/yes & $2.58(0.76-8.83)$ & 0.13 & & \\
\hline Diabetes Mellitus & no/yes & & 0.366 & & \\
\hline Type of treatment ${ }^{3}$ & $\begin{array}{l}\text { INF+RBV/ } \\
\text { PEGINF+RBV }\end{array}$ & $1.78(0.47-6.7)$ & 0.40 & $2.06(0.52-8.23)$ & 0.30 \\
\hline
\end{tabular}


lin resistance have a worse response to treatment with PEGINF + RBV. ${ }^{22.23}$

This study found that after 24 weeks of treatment, patients with genotype 3 have 2.5 times higher risk of treatment interruption than patients with genotype 1 . In the literature, studies have reported an association of genotype 1 with treatment interruption, since the prescribed therapy duration is usually longer for these individuals than for genotype 3, which would increase the chances of side effects. ${ }^{78,9}$ It is possible that methodological differences may explain the different results. In the present study, the association between genotype and treatment interruption was detected after 24 weeks, and the duration of therapy prescribed was the same for all 104 patients analyzed at this point (48 weeks).

In conclusion, degree of hepatic fibrosis and genotype proved to be the major risk factors associated with treatment interruption. The treatment of hepatitis $C$ was stopped by $27.9 \%$ of patients in this study. In the literature, several studies can be found that evaluated the side effects of the therapy as a cause of treatment interruption, but few studies have evaluated the influence of other risk factors associated with treatment discontinuation. Additional prospective studies with larger sample sizes may be useful to clarify the influence of risk factors on treatment interruption.

\section{Acknowledgements}

The authors thank Dr. Paulo de Tarso, head of the Hepatology service at HSE, Dr. Claudia Escosteguy, head of the Epidemiology service at HSE, and Professor Haroldo José de Matos, from the Epidemiology service at HSE.

\section{Resumo}

Objetivo: avaliar os fatores de risco relacionados à interrupção do tratamento da hepatite $C$.

Métodos: coorte histórica dos pacientes atendidos no ambulatório de Hepatologia do Hospital dos Servidores do Estado do Rio de Janeiro, de 2001 a 2009. Os fatores investigados foram: idade, sexo, genótipo, grau de fibrose hepática, tipo de tratamento, tempo de tratamento em emanas, diabetes mellitus e hipertensão arterial sistêmica. Curvas de sobrevida e modelos de regressão Cox bivariados e multivariados foram utilizados nas análises.

Resultados: o risco de interrupção do tratamento é seis vezes maior em pacientes com o grau mais avançado de fibrose hepática (F4) do que naqueles com grau menos avançado (F2), no período de 0 a 24 semanas de ratamento. O genótipo mostrou ser importante fator para explicar a suspensão do tratamento a partir da $24^{\mathrm{a}}$ semana de tratamento - o risco de interromper o tratamento foi 2,5 vezes maior em pacientes com genótipo 3 do que os com genótipo 1.

Conclusão: o grau de fibrose hepática e o genótipo mostraram-se os principais fatores de risco associados à interrupção do tratamento.

Unitermos: hepatite C; interferon; ribavirina; interrupção do tratamento; fatores de risco.

\section{REFEREnCES}

1. Lavanchy D. The global burden of hepatitis C. Liver Int 2009; 29(Suppl.1):74-81.

2. Ministério da Saúde. Secretária de Vigilância em Saúde, Departamento de DST, Aids e Hepatites Virais. Protocolo clínico e diretrizes terapêuticas para hepatite viral C e coinfecções. Brasília (DF): Ministério da Saúde, 2011.

3. Garcia TJ, Lara PHS, Morimoto TP, Higasiaraguti M, Perejão AM, Ayub MA. Efeitos colaterais do tratamento da hepatite $\mathrm{C}$ no polo aplicador do $\mathrm{ABC}$. Rev Assoc Med Bras 2012; 58(5):543-9.

4. Liang TJ, Rehermann B, Seeff LB, Hoofnagle JH. Pathogenesis, natural history, treatment, and prevention of hepatitis C. Ann Intern Med 2000; 132(4):296-305.

5. Hoofnagle JH, Seeff LB. Peginterferon and ribavirin for chronic hepatitis C. N Engl J Med 2006; 355:2444-51.

6. Reddy KR, Wright TL, Pockros PJ, Shiffman M, Everson G, Reindollar R et al. Efficacy and safety of pegylated (40-kd) interferon alpha-2a compared with interferon alpha-2a in non cirrhotic patients with chronic hepatitis C. Hepatology 2001; 33(2):433-8.

7. Ministério da Saúde. Secretaria de Vigilância em Saúde. SAS/MS Portaria n. 34 de 23 set. 2007. Dispõe sobre protocolo clínico e diretrizes terapêuticas para hepatite viral C. Brasília (DF): Ministério da Saúde, 2007.

8. Manns MP, McHutchison JG, Gordon SC, Rustgi VK, Shiffman M, Reindollar et al. Peginterferon alfa- $2 \mathrm{~b}$ plus ribavirin compared with interferon alfa- $2 \mathrm{~b}$ plus ribavirin for initial treatment of chronic hepatitis C: A randomised trial. Lancet 2001; 358(9286):958-65.

9. Fried MW, Shiffman ML, Reddy KR, Smith C, Marinos G, Gonçales Jr. FL et al. Peginterferon alfa-2a plus ribavirin for chronic hepatitis $\mathrm{C}$ virus infection. N Engl J Med 2002; 347(13):975-82.

10. Hadziyannis SJ, Sette H Jr, Morgan TR, Balan V, Diago M, Marcellin P et al. Peginterferon-alpha2a and ribavirin combination therapy inchronic hepatitis $\mathrm{C}$ : a randomized study of treatment duration and ribavirin dose. Ann Intern Med 2004; 140(5):346-55.

11. Simmonds P, Bukh J, Combet C, Deleage G, Enomoto N, Feinstone S et al. Consensus proposals for a unified system of nomenclature of hepatitis C virus genotypes. Hepatology 2005; 42(4):962-73.

12. Campiotto S, Pinho JR, Carrilho FJ, Da Silva LC, Souto FJ, Spinelli V et al. Geografic distribution of hepatitis C vírus genotypes in Brazil. Braz J Med Biol Res 2005; 38(1):41-9.

13. Everson GT. Treatment of chronic hepatitis $C$ in patients with decompensated cirrhosis. Rev Gastroenterol Disord 2004; 4(Suppl 1):S31-8.

14. Kim HI, Kim IH, Jeon BJ, Lee S, Kim SH, Kim SW et al. Treatment response and tolerability of pegylated interferon- $\alpha$ plus ribavirin combination therapy in elderly patients ( $\geq 65$ years) with chronic hepatitis $C$ in Korea. Hepat Mon 2012; 12(7):430-6.

15. Deutsch M, Dourakis S, Manesis EK, Gioustozi A, Hess G, Horsch A et al. Thyroid abnormalities in chronic viral hepatitis and their relationship to interferon alfa therapy. Hepatology 1997; 26(1):206-10.

16. Arase Y. Viral hepatitis: Impact of adherence to combination therapy for hepatitis C. Nat Rev Gastroenterol Hepatol 2011; 8(5):248-9.

17. Schmid M, Kreil A, Jessner W, Homoncik M, Datz C, Gangl A et al. Suppression of haematopoiesis during therapy of chronic hepatitis $C$ with different interferon alpha mono and combination therapy regimens. Gut 2005; 54(7):1014-20.

18. Sherman KE. Managing adverse effects and complications in completing treatment for hepatitis C virus infection. Top Antivir Med 2012; 20(4):125-8.

19. Almawardy R, Elhammady W, Mousa N, Abotaleb S. Combination therapy for chronic hepatitis C toxic for cardiac function? Hepat Mon 2012; 12(8):e6254. 
20.

Okan V, Araz M, Aktaran S, Karsligil T, Meram I, Bayraktaroglu Z et al. Increased frequency of $\mathrm{HCV}$ but not $\mathrm{HBV}$ infection in type 2 diabetic patients in Turkey. Int J Clin Pract 2002; 56(3):175-7.

21. Metha SH, Brancatti FL, Strathdee SA, Pankow JS, Netski D, Coresh J et al. Hepatitis C virus infection and incident type 2 diabetes. Hepatology 2003; 38(1):50-6.
22. Romero-Gómez M, Del Mar VM, Andrade RJ, Salmerón J, Diago M, Fernández RCM et al. Insulin resistance impairs sustained response rate to peginterferon plus ribavirin in chronic hepatitis C patients. Gastroenterology 2005; 128(3):636-41.

23. Khattab M, Eslam M, Sharwae MA, Shatat M, Ali A, Hamdy L. Insulin resistance predicts rapid virologic response to peginterferon/ribavirin combination therapy in hepatitis C genotype 4 patients. Am J Gastroenterol 2010; 105(9):1970-7. 